Original Article

\title{
Effects of Artemisia A. Smoke(Ssukjahun) on Menstrual Distress, Dysmenorrhea, and Prostaglandin F2 $\alpha$
}

\author{
Lee, Kwang $\mathrm{Ok}^{1)} \cdot \mathrm{Kim}, \mathrm{Sue}^{2)} \cdot$ Chang, Soon $\mathrm{Bok}^{3)} \cdot$ Yoo, Ji Soo ${ }^{2)}$ \\ 1) Research Professor, College of Nursing, Seoul University, Seoul \\ 2) Professor, College of Nursing, Nursing Policy Research Institute, Yonsei University \\ 3) Emeritus Professor, College of Nursing, Yonsei University

\section{쑥좌훈이 월경불편감, 월경통강도, Prostaglandin F2 $\alpha$ 에 미치는 효과$$
\text { 이광옥 }{ }^{1)} \cdot \text { 김 } \text { 수 }^{2)} \cdot \text { 장순복 }^{3)} \cdot \text { 유지수 }^{2)}
$$ \\ 1) 서울대학교 간호대학 연구교수, 2) 연세대학교 간호대학 교수, 간호정책연구소 \\ 3) 연세대학교 간호대학 명예교수
}

\section{Abstract}

Purpose: The purpose of this study was to identify effects of Artemisia A. Smoke(Ssukjahun) on primary dysmenorrhea. Method: This study was a pretestposttest design with a nonequivalent control group. Data were collected from May 1, 2007 to May 27, 2008. A total of 40 women with dysmenorrhea participated in the study. Among them, 20 women were assigned to an experimental group and the other 20 to a control group. Artemisia A. Smoke(Ssukjahun) was provided daily for 4 days, starting 7 days prior to next expected menses in the experimental group. The instruments used in this study included MDQ (Moos' Menstrual Distress Questionnaire) by Kim (1995), Visual Analogue Scale by Keele (1948), and PGF2 $a$ by urine. Result: The results of this study are as follows; The experimental group was lower than the control group in the degree of menstrual distress $(t=5.25, p=0.000)$, intensity of dysmenorrhea $(t=7.71$, $\mathrm{p}=0.000)$, and prostaglandin F2a levels $(\mathrm{t}=4.56, \mathrm{p}=$ 0.000). Conclusion: Artemisia A. Smoke (Ssukjahun) was proved as an effective nursing intervention to reduce dysmenorrhea in young women. Its convenience and accessibility may make it a useful intervention in nursing practice and education.

Key words : Nursing intervention, Menstrual distress, Dysmenorrhea, Prostaglandin F2 $\alpha$

\section{서 론}

\section{1. 연구의 필요성}

월경통은 월경 때 하복부, 자궁 부위에 생기는 통증 $(\mathrm{Ji}$, 2004)으로 청소년기 여성의 85\%(Chantay Banikarim, Mariam, Chacko, \& Kelder, 2000) 내지 93\%(Campbell \& McGrath,

투고일: 2009. 5. 15 1차심사완료일: 2009. 6. 2 최종심사완료일: 2009. 6. 10

- Address reprint requests to : Kim, Sue(Corresponding Author)

College of Nursing, Yonsei University

134 Sinchondong Seodamungu Seoul City

Tel: 82-2-2228-3276 Fax:82-2-392-5440 E-mail: Suekim@yuhs.ac.kr 
1997)에서 경험하는 가장 흔한 부인과적 문제로서, 매년 250 만 명의 여성들이 월경통으로 인해 고생하며 삶의 질에 크게 영향을 미치고 있다(Clayton, 2008). Dawood(1988)는 극심한 월경통으로 인해 매년 6 억의 작업시간 손실이 오며 20 억의 경제적 손실을 가져온다고 하였으며, 이는 경제적 손실 뿐 만 아니라 신체적, 정신적인 문제에 있어서도 우리가 심각하게 고민하고 해결해야할 과제이다.

월경통의 원인이 되는 기전으로는 폐쇄적인 해부학적 요소, 정신적 요소, 내분비적 요소로 여성호르몬과 황체호르몬의 불 균형설, Prostaglandin 호르몬설 등이 거론되고 있으나 그중 가장 유력한 생리·병리학적 이론은 Prostaglandin의 자궁근육 활성화설이다. 월경과 관련해 내분비적 현상으로 prostaglandin $\mathrm{F} 2 \alpha$ 를 합성하고 이것은 자궁수축을 발생시켜 자궁의 국소빈 혈을 일으키고 신경말단의 통증에 대한 역치를 낮추는 기전 에 의해 월경통이 유발된다. 심한 월경통을 호소하는 여성들 에게 월경 혈의 prostaglandin $\mathrm{F} 2 \alpha$ 를 분석한 결과 그렇지 않은 여성들보다 높게 나타났다(Coco, 1999). Pickles, Hall, Best, \& Smith(1965)는 prostaglandin F2 $\alpha$ 를 사람에게 주입하니 월경통 의 전형적인 증상이 나타났고 prostaglandin 합성 억제제가 월 경통에 효과가 있어 자궁근육의 수축빈도 및 강도를 줄인다 고 했다.

월경통을 경험하는 여성들은 증상을 완화하기 위하여 진통 제나 경구피임제 같은 약물요법이나 휴식, 보온과 지지, 운동, 마사지, 전환 요법 등의 비 약물적 요법을 사용하고 있으며 (Kim \& Hwang, 2005), 이 가운데 진통제 복용은 월경통을 경험하는 여성들이 가장 빈번히 사용하는 통증완화 방법이다 (Han, Ro, \& Hur, 2001).

월경통 완화를 위해 주로 사용되고 있는 prostaglandin 합성 억제제는 cyclooxygenase를 억제하여 cyclic endoperoxide 합성 을 억제하는 Indomethacin, Naproxen, Ibuprofen, Mefenamic acid등(NSAIDs)으로, NSAIDs를 투여할 때에는 통증이 시작되 기 직전부터 6-8시간마다 월경 시작 후 며칠 동안 복용해야만 하고, 투여후 만족스럽지 못할 때는 NSAIDs 종류와 용량을 바꾸어 가며 최소한 4-6개월간 치료해보는 것이 바람직하다고 하였다(Kim, 2005). 그러나 이러한 장기적인 약물복용은 유방 동통, 유즙분비과다증, 신경과민, 불면증, 경련, 피로 또는 현 기증, 혈전성 정맥염, 폐동맥색 전증 등의 혈전색전증 현상, 두드러기, 소양증, 맥관 신경성 부종 및 아나필락시스등의 과 민반응, 원형탈모증, 구역, 위장관계 독성, 드물게 황달, 두통, 이상고열증, 점상출혈, 월경량 변화 등 여러 부작용을 야기시 킬 뿐만 아니라(Korean Association of Obstetricans and Gynecologist, 1991; Warner et al, 1999), 중요한 것은 이러한 약물요법이 $15 \sim 20 \%$ 의 중증의 월경통 대상자들에게는 전혀 효과가 없다고 보고된 바 있다(Dawood, 1988). 그러므로 좀
더 효과적인 월경통 완화를 위한 비 약물적 대처방안의 모색 이 필요하다고 본다.

쑥좌훈(Artemisia A. Smoke)은 고대한방에서 사용하던 치료 법 중의 하나로 동의보감에는 훈제비방(薰臍秘方), 소연훈지 (燒烟熏之)라 하여 훈증에 대한 묘사가 있고 $(\mathrm{Hu}, 2002)$, 황제 내경에도 훈증(熏蒸)에 대한 기록이 있어 당시에 질병치료의 수단으로 훈증을 사용하였음을 알 수 있다(Choi, 1999). 쑥은 높이 약 $80 \mathrm{~cm}$ 되는 여러해살이 풀로 특성은 따뜻하고 독이 없 으며 약리작용은 지혈작용과 해열, 혈압하강, 소염, 항균, 호 흡촉진, 그람양성균, 피부진균 작용에 효과가 있으며 특히 부 인병에 효과가 있는데 쑥의 따뜻한 성격과 수렴성 지혈과 자 궁의 운동성을 감소시킴에 따라 오래전부터 월경통 완화를 위한 치료에 이용되어져 왔다(Korean Association of Obstetricans and Gynecologist, 1991; Choi, 1999). 쑥 성분들 중 특히 isothujone(Rice \& Wilson, 1976), linalool(Peana et al., 2003), 그리고 cineol(Santos \& Rao, 2000)등 17개의 monoterpene 성분들이 통증완화, 항염증작용, 조직손상억제효 과를 준다고 보고되었다. 세균발육을 억제시키는 쑥의 항염증 성분중의 하나로(Huang et al., 1993) scopoletin(Won, 2003)과 linalool(Peana, Marzocco, Popolo, \& Pinto, 2006)은 LPS에 의 하여 nitric oxid(NO)의 생성을 억제시켰고, 염증유발물질인 LPS 자극에 의한 대식세포주 세포의 iNOS의 생성을 억제시 켰다. 또한 scopoletin과 linalool은 세포의 COX-2의 생성을 의 존적으로 억제시킴으로 prostaglandin 합성을 억제시켰다. 쑥의 항염증성분중 copa extract도 통증완화와 항염증작용을 유도하 였으며(Mino et al., 2004), Park, Yu, Lee, \& Kim(1994)은 쑥 의 메탄올 추출물을 이용하여 항염증 및 진통작용을 관찰한 결과 유의한 항염증 활성을 나타낸다고 하였다. 최근연구에 의하면 쑥 성분중 1, 8-Cineol(cineol)은 COX-2 생성을 억제시 켜 prostaglandin 합성을 억제시키고, 항염증제와 진통제로서 아주 유용한 성분임을 증명하였다(Santos \& Rao, 2000). 쑥좌 훈의 월경통 감소에 대한 효과를 설명하는 흡수경로를 살펴 보면, 쑥좌훈시 쑥 안의 several monoterpene 성분들이 피부 점막을 통해 흡수되고, 이것이 혈관을 통해 조직, 기관으로 들어가 prostaglandin 합성을 억제시켜 자궁근육의 이완을 유 도하고, 혈류증가를 통한 하복부위의 피부온도 상승으로 월경 통 완화에 효과적으로 반응한다고 추정된다.

이에 본 연구에서는 월경통을 prostaglandin설에 근거해, 원 발성 월경통을 경험하는 여성들에게 월경 예정일 7일전부터 1 일 1회 30 분간 4 일간 쑥좌훈을 적용해봄으로써 쑥 좌훈이 prostaglandin F2 $\alpha$ 합성을 억제하여 월경통을 완화시킬 수 있 는 효과적인 방법인지 규명하고자 한다. 또한 쑥좌훈의 과학 성과 합리성을 증명함으로써 월경통을 경험하는 여성들에게 편안하게 건강행위를 하도록 돕고 이것이 대상자들의 삶의 
질 향상에 긍정적으로 기여할 수 있도록 하는 간호학적인 중 재 전략으로 개발하고자 한다.

\section{2. 연구 목적}

본 연구의 목적은 쑥좌훈이 월경통에 미치는 효과를 검증 하여 간호중재로서의 타당성을 규명하기 위함이다.

- 쑥좌훈이 월경불편감에 미치는 효과를 규명한다.

- 쑥좌훈이 월경통 강도에 미치는 효과를 규명한다.

- 쑥좌훈이 prostaglandin F2 $\alpha$ 농도에 미치는 효과를 규명한다.

\section{3. 연구 가설}

- 쑥좌훈을 시행한 실험군은 시행하지 않은 대조군보다 월경 불편감이 낮을 것이다.

- 쑥좌훈을 시행한 실험군은 시행하지 않은 대조군보다 월경 통 강도가 낮을 것이다.

- 쑥좌훈을 시행한 실험군은 시행하지 않은 대조군보다 prostaglandin F2 $\alpha$ 농도가 낮을 것이다.

\section{4. 용어 정의}

1) 쑥좌훈

쑥을 태워 그 연기나 열로 회음부를 통해 온 전신에 쑥의 양기를 보내는 것( $\mathrm{Hu}, 1997)$ 으로 본 연구에서는 W좌훈방의 좌훈기를 사용하여 월경예정 7 일 전 부터 1 일 1 회 30 분씩 4 일간 쑥(강화약쑥 $40 \mathrm{~g}$ )연기를 회음부에 쏘임을 말한다.

\section{2) 월경불편감}

월경기동안 여러 가지 형태의 신체적, 정서적 또는 행동적 인 증상으로 본 연구에서는 $\operatorname{Moos}(1968)$ 가 개발한 $\mathrm{MDQ}$ (Menstrual Distress Qestionaire) 측정도구를 $\mathrm{Kim}(1995)$ 이 간편 화시킨 35 문항 6 점 척도의 도구로 측정한 점수를 말한다. 점 수가 높을수록 월경불편감의 정도가 큰 것을 의미한다.

\section{3) 월경통}

월경 때 하복부, 자궁 부위에 생기는 통증으로 자궁이나 난
소에 이상이 없이 경험하는 원발성 통증 $(\mathrm{Ji}, 2004)$ 을 말하며 본 연구에서는 Keele(1948)의 Visual Analogue Scale(VAS)로 측정한 점수를 말한다. 점수가 높을수록 월경통의 강도가 큰 것을 의미한다.

\section{4) Prostaglandin F2 $\alpha$}

리놀레인산으로부터 자체 합성되는 $\mathrm{C}_{20}$ 불포화 지방산인 아 라키돈산으로부터 생합성되는 지혈과 염증, 통증에 관계하는 국소호르몬으로(The Korean Society of pathologists, 2003), 본 연구에서는 소변 $10 \mathrm{ml}$ 를 Eppendorf용기에 채취하여 분석한 것을 말하며 수치가 높을수록 prostaglandin F2 $\alpha$ 농도가 높은 것을 나타낸다.

\section{연구 방법}

\section{1. 연구 설계}

본 연구는 쑥좌훈이 월경통에 미치는 효과를 검증하기 위한 유사실험 연구로 비동등성 대조군 전후설계이다(Figure 1).

\section{2. 연구 대상}

본 연구대상자는 경기도 거주 만 16 세 이상 30 세 미만 40 명으로서 선정 기준은 다음과 같다.

- 월경 주기가 최소 3 개월 이상 규칙적이었고 28-35일 주기인 자

- 월경통 통증상사척도(VAS)상 4.0 이상인 자

- 골반염증성 질환, 자궁내막증의 기왕력이 없는 자

- 분만경험이 없는 자

- 연구기간 중 진통제 복용이나 온찜질 등을 사용하지 않는 자

- 연구기간 중 경구피임약을 복용하지 않는 자

- 심한 정서적 문제나 정신 병력이 없는 자

- 쑥좌훈 경험이 없는 자

- 연구 목적을 이해하고 참여에 동의한 자

연구대상 표본수는 유의수준 $\alpha=0.05$, 효과크기 0.50 , 검정 력 0.80 으로 하여 Cohen 공식을 이용하여 구했을때, 각 실험 군 대조군 17 명으로 총 34 명의 표본수가 구해졌다. 연구대상

\begin{tabular}{cccc}
\hline \multirow{2}{*}{$n$} & 1 menstrual cycle & \multicolumn{2}{c}{2 menstrual cycle } \\
\cline { 2 - 4 } & Pretest & Intervention & Posttest \\
\hline Exp. group(20) & Ye1 & $\mathrm{x}$ & Ye2 \\
Cont. group(20) & Yc1 & - & Yc2 \\
\hline
\end{tabular}

Ye1, Yc1: general questionare, the degree of menstrual distress questionnaire, the intensity of dysmenorrhea, and prostaglandin F2a level Ye2, Yc2: the degree of menstrual distress questionnaire, the intensity of dysmenorrhea, and prostaglandin F2a level

$\mathrm{x}$ : Wormwood smoke(Ssukjahun)

Figure 1. Research design 
자는 대상자선정 설문지를 작성하게 한 뒤 연구 참여자들을 단순 무작위 표출방법으로 순서대로 실험군 대조군에 배정하 여 실험을 진행하였으나 실험 처치도중 실험군 8 명, 대조군 7 명이 연구 참여를 포기하거나, 개인 사정으로 4일간 실험처치 를 받지 못한 이유 등으로 중도 탈락하였고, 표본수가 채워질 때까지 실험처치를 지속하여 실제 연구 참여자수는 실험군 20 명, 대조군 20 명으로 총 40 명이었다.

\section{3. 연구 도구}

본 연구에서 사용한 도구는 다음과 같다.

1) 일반적 특성

일반적 특성에는 대상자의 연령, 체중, 초경연령, 월경주기, 월경혈양, 월경통기간, 월경통 대처방법 등 7 문항으로 구성되 어 있다.

2) 월경불편감 측정 도구

월경불편감 측정도구는 $\operatorname{Moos}(1968)$ 의 Menstrual Distress Questionnaire(MDQ)를 Kim(1995)이 간편화한 것으로 6개 범 주 즉 통증, 집중력저하, 행동의 변화, 자율신경계 반응, 수분 축적, 부정적정서로 6 점 척도의 35 문항으로 구성된 도구이다. 측정 시기는 월경시작 48 시간 이내로 연구 참여자를 만나 자 가보고 하도록 하였으며, 점수가 높을수록 월경불편감이 심하 다는 의미이며 점수는 35 점에서 210 점 까지 이다. $\mathrm{MDQ}$ 신뢰 도는 내적일관성을 검사한 결과 Cronbach's a가 .97이었다.

3) 월경통 강도 측정 도구

월경통 강도는 Keele(1948)의 시각적 상사척도(VAS)로 측정 하였으며 측정시기는 월경시작 48 시간이내 연구 참여자를 만 나 자가보고 하도록 하였다.

\section{4) $\mathrm{PGF} 2 \alpha$ 측정 도구}

월경시작 48 시간이내 가장 통증이 심한 시점에서 소변을 Eppendorf 검체 용기에 채취하여 입구를 태워 막은 뒤, $-25^{\circ} \mathrm{C}$ 이하에서 냉동보관한 후 서울의과학연구소로 의뢰하여 ELISA (Enzyme- Linked ImmunoSorbent Assay)방법으로 분석하였다.

\section{4. 자료 수집 절차}

본 연구는 2007년 5월부터 2008년 5월까지 연구대상자를 선정하여 IRB승인, 연구 참여자 확보, 예비실험, 사전조사, 실 험처치, 사후조사의 순으로 진행하였다.

\section{1) 연구참여자 확보과정}

대상자로 선정되어 자원한 참여자들에게 연구내용, 절차, 가능 부작용, 원할시에는 언제든지 연구 참여를 중단할 수 있 다는 내용 등에 대해 충분히 설명하고 서면화된 동의서에 서 명을 받았다. 여고생의 경우에는 부모의 동의를 받은 후 진행 하였다.

2) 예비실험

연구의 실행가능성과 연구 설계를 강화하고 연구도구의 검 증을 위해 예비실험을 하였다. 도구의 적절성, 민감성을 높이 기 위해 쑥좌훈 실험처치 방법을 설정하기 위하여 모집단에 유사한 대상자 10 명을 대상으로 예비실험을 하여 쑥좌훈을 적용하고 보완하였다. 문헌으로부터 근거한 좌훈 유지 온도를 $40-45^{\circ} \mathrm{C}$ 로, 월경통에 가장 효과적으로 반응한 약쑥 $40 \mathrm{~g}$, 쑥좌 훈을 적용 하였을때 월경통에 가장 바람직한 효과가 나타난 최소기간 4일을 선택하였다. 쑥좌훈 하는 동안 열기로 인해 화상, 수포, 발적등의 부작용이 일어나는지 관찰하였으며 특 별한 부작용은 없었다.

\section{3) 사전조사}

대상자에게 월경시작 48 시간 이내 통증이 가장 심한시점에 서 일반적 특성, 월경불편감, 월경통 강도를 측정하였고, prostaglandin $\mathrm{F} 2 \alpha$ 측정을 위해 Eppendorf검체 용기에 소변을 채취하여 연구자가 입구를 태운 후, 검체를 $-25^{\circ} \mathrm{C}$ 이하에서 냉 동보관 하였다.

4) 실험처치

(1) 쑥좌훈 처지 적용 근거

월경예정일 7일전부터 쑥좌훈을 적용하려고 하는 근거는, prostaglandin의 과도한 수축에 관하여 자궁내막의 분비기에 prostaglandin F2a 합성이 많아져 평활근 수축에 관여하기 때 문에(Korean Association of Obstetricans and Gynecologist, 1991), prostaglandin F2 $\alpha$ 수치가 높게 올라가기 전의 월경예 정 7일전부터(월경전기) 쑥좌훈을 적용하여 월경통 완화를 도 모하고자 하였다. 또한 월경불편감은 월경전기에 심하고 이것 이 월경기로 이어지고(Kim, 1995), Facchinetti 등((1989)이 NSAIDS(naproxen)를 다음 월경시작 7일전부터, 1일 2회, 4일 간 투여하여, Moos의 $\mathrm{MDQ}$ 로 분석한 결과 월경중 통증과 월 경전 통증 모두 감소시킨 결과를 토대로 쑥좌훈을 적용해 보 고자 하였다.

약쑥 $40 \mathrm{~g}$ 을 사용하는 근거는, 쑥의 1 일 복용양으로 $4-12 \mathrm{~g}$, 외용으로 적당량을 사용하도록 본초학(Professor, University of oriental medicine, 2000)에 명시되어 있기에, 예비실험에서 10 명을 대상으로 $12 \mathrm{~g}$ 부터 시작하여 월경통 완화에 가장 효과적 
으로 반응하는 용량이 될 때까지 $20 \mathrm{~g}, 30 \mathrm{~g}, 40 \mathrm{~g}$ 을 적용해 본 결과 월경통에 가장 효과적으로 반응하고, 열 요법에 적정온 도인 $40-45^{\circ} \mathrm{C}$ 를 유지하며, 본 연구에 사용될 좌훈기의 크기에 맞추어 $40 \mathrm{~g}$ 을 적용하였다. 이후 약쑥 $40 \mathrm{~g}$ 을 4 일, 3 일, 2 일을 적용해 본 결과, 2 일까지는 효과가 없었고, 3 일부터 월경통 완화 효과를 보였으나 월경통 완화에 가장 이상적으로 반응 하는 시점인 4 일간을 적용 하였다. 30 분간 사용하는 것은 열 요법의 효과가 $40-45^{\circ} \mathrm{C}$ 에서 약 30 분간 지속될 때 나타나고 30 분 이상 열을 지속적으로 적용하면 조직의 울혈과 혈관수 축이 오며, 조직 대사도 감소될 수 있으므로 문헌에 근거하여 30 분 동안 쑥좌훈을 적용하였다(Hayes, 1993).

(2) 쑥좌훈 하는 방법

(1) 좌훈기를 평평한 바닥에 위치하고 쑥, 치마, 점화장치 (라이터)를 준비한다.

(2) 치마를 착용하고 속옷은 탈의 한다.

(3) 약쑥 $40 \mathrm{~g}$ 을 좌훈기 중앙 그릇에 담는다.

(4) 점화 도구를 사용하여 쑥에 점화 시킨다.

(5) 쑥이 담긴 그릇을 본체 중앙 바닥에 올려놓는다.

(6) 밖으로 연기가 새어나가지 않도록 치마로 좌훈기를 완 전히 덮은 상태에서 좌훈기위에 편안하게 착석하여 30 분 동안 그 열기를 쏘인다.

(7) 안전수칙: 실험처치를 하는 동안 회음부의 화상 등의 부작용 예방을 위해 쑥좌훈 하는 동안 뜨거움이 느껴 지거나 통증 및 기타 부작용이 있을시 바로 알리도록 하였으며, 불편감 및 부작용이 있을 시에는 적절한 조 치를 취할 수 있도록 쑥좌훈 하는 동안 연구자가 대 상자와 함께 있었다. 처치 후에도 수포 발적, 통증, 기

타 다른 불편감이 발생할 시 즉시 연구자에게 전화하 도록 하였으나 부작용이 일어난 대상자는 없었다.

5) 사후조사

쑥좌훈 처치 후 다음 월경시작 48시간 이내 통증이 가장 심한 시점에서 월경불편감, 월경통 강도를 측정하였다. Prostaglandin $\mathrm{F} 2 \alpha$ 측정을 위해 Eppendorf검체 용기에 소변을 채취하여 검 체를 $-25^{\circ} \mathrm{C}$ 이하에서 냉동보관 하였다.

연구가 끝나고 대조군 중에서 쑥좌훈을 받기 원하는 대상 자에게는 쑥좌훈을 제공하였다.

\section{5. 자료 분석}

자료분석은 SPSS 12.0 을 사용하였다.

- 연구 대상자의 일반적 특성은 기술통계로 실수, 빈도, 평균 을 산출하였다.

- 실험군과 대조군의 동질성 검증은 x2-test 와 t-test를 이용하 였다.

- 월경통의 중재효과는 paired t-test, 두군간 차이는 t-test로 하 였다.

\section{연구 결과}

연구 대상자의 특성 및 연구 집단 간의 동질성 검증과 가 설검증을 위한 분석결과는 다음과 같다.

\section{1. 대상자 특성}

Table 1. Demographic characteristics and homogeneity of the experimental and control group

$(\mathrm{N}=40)$

\begin{tabular}{|c|c|c|c|c|c|c|c|c|}
\hline \multirow{2}{*}{\multicolumn{2}{|c|}{ Variable }} & \multirow{2}{*}{ Categories } & \multicolumn{2}{|c|}{ Exp. $\operatorname{group}(n=20)$} & \multicolumn{2}{|c|}{ Cont. $\operatorname{group}(n=20)$} & \multirow{2}{*}{$\chi^{2}$ or $t$} & \multirow[b]{2}{*}{$\mathrm{p}$} \\
\hline & & & $f(\%)$ & $\mathrm{M} \pm \mathrm{SD}$ & $f(\%)$ & $\mathrm{M} \pm \mathrm{SD}$ & & \\
\hline \multicolumn{3}{|l|}{ Age } & & $20.50 \pm 5.11$ & & $18.50 \pm 3.90$ & 1.39 & .173 \\
\hline \multicolumn{3}{|l|}{ Weight $(\mathrm{kg})$} & & $51.80 \pm 6.88$ & & $50.05 \pm 4.89$ & 0.93 & .360 \\
\hline \multicolumn{3}{|c|}{ First menstruation age } & & $12.10 \pm 0.85$ & & $12.55 \pm 0.89$ & -1.64 & .110 \\
\hline \multicolumn{3}{|c|}{ Duration of menstruation (day) } & & $5.90 \pm 1.21$ & & $6.20 \pm 1.28$ & -0.76 & .451 \\
\hline \multicolumn{2}{|c|}{ Duration of pain(day) } & & & $3.15 \pm 1.31$ & & $2.75 \pm 0.85$ & -0.76 & .259 \\
\hline \multirow{3}{*}{\multicolumn{2}{|c|}{ Amount of menstruation blood }} & Much & $6(30)$ & & $5(25)$ & & & \\
\hline & & Moderate & $12(60)$ & & $14(70)$ & & 0.58 & .75 \\
\hline & & Little & $2(10)$ & & $1(5)$ & & & \\
\hline \multirow{2}{*}{\multicolumn{2}{|c|}{ Smoking }} & Yes & $2(10)$ & & $4(20)$ & & 078 & \\
\hline & & No & $18(90)$ & & $16(80)$ & & 0.78 & .66 \\
\hline \multirow{6}{*}{ Pain control } & \multirow[t]{2}{*}{ Medication } & Yes & $17(85)$ & & $11(55)$ & & \multirow{2}{*}{4.29} & \multirow{2}{*}{.08} \\
\hline & & No & $3(15)$ & & $9(45)$ & & & \\
\hline & \multirow[t]{2}{*}{ Heating pad } & Yes & $11(55)$ & & $12(60)$ & & \multirow{2}{*}{0.10} & \multirow{2}{*}{1.0} \\
\hline & & No & $9(45)$ & & $8(40)$ & & & \\
\hline & \multirow[t]{2}{*}{ Abdomen massage } & Yes & $7(35)$ & & $5(25)$ & & \multirow{2}{*}{0.48} & \multirow{2}{*}{.73} \\
\hline & & No & $13(65)$ & & $15(75)$ & & & \\
\hline
\end{tabular}

Exp.=experimental; Cont. $=$ control 
1) 대상자의 일반적 특성

실험군과 대조군의 일반적 특성의 분포에 따른 동질성 검 증은 Table 1 과 같다. 연구 대상자는 실험군 20 명, 대조군 20 명으로 총 40 명이었다.

실험군의 연령은 평균 20.5 세 $( \pm 5.11)$ 이었고, 체중은 $51.80 \mathrm{~kg}$ ( \pm 6.88$)$, 초경연령은 12.10 세 $( \pm 0.85)$ 였다. 월경혈양은 대부분이 보통양이 12 명 $(69 \%)$ 이었으며, 월경기간은 $5.90( \pm 1.21)$ 일, 통증 기간은 $3.15( \pm 1.31)$ 일 이었다. 흡연은 안한다가 18 명 $(90 \%)$, 월 경통시 대처방법으로는 약물복용 하는 경우가 17 명 $(85 \%)$, 온 찜질 9명(45\%), 복부 마사지 7 명(35\%)순이었다. 대조군의 연 령은 18.50 세 $( \pm 3.90)$ 이었고, 체중은 $50.05 \mathrm{~kg}( \pm 4.89)$, 초경연령은 12.55 세( \pm 0.89$)$ 였다. 월경혈양은 대부분 보통이었으며(14명, $70 \%)$ 월경기간은 6.20 일 $( \pm 1.28)$, 통증기간은 2.75 일 $( \pm 0.85)$ 이였 다. 월경통시 대처방법으로는 온찜질한다가 12 명 $(60 \%)$ 으로 가 장 많았으며, 약물복용을 하는 경우가 11 명 $(55 \%)$, 복부마사지 5 명 $(25 \%)$ 순이었다.

이상으로 볼 때 두 집단 간 일반적 특성에 따른 동질성을 $\chi$ 2 -test와 t-test를 통해 비교해 본 결과 유의한 차이가 없어 두
집단은 동질한 것으로 나타났다.

2) 쑥좌훈 실시전 실험군과 대조군의 제변수 특성

실험처치 전 두 집단간 동질성 검증을 한 결과, 월경불편감 점수는 실험군이 124.7 점 $( \pm 35.78)$, 대조군이 114.85 점 $( \pm 28.49)$ 으로 나타났다. 월경통점수는 실험군이 8.08 점 $( \pm 1.42)$, 대조군 7.5점 $( \pm 1.58)$ 으로 나타났으며 소변 내 prostaglandin F2 $\alpha$ 는 실 험군이 $1.26 \mathrm{ng} / \mathrm{ml}( \pm 0.26)$, 대조군이 $1.25 \mathrm{ng} / \mathrm{ml}( \pm 0.20)$ 였다. 두 군간 제 변수에 대한 실험처치 전 t-test를 통해 동질성을 비 교해 본 결과 통계적으로 유의한 차이가 없어 두 군은 동질 한 것으로 나타났다(Table 2).

\section{2. 가설 검증}

1) 쑥좌훈이 월경불편감에 미치는 효과

실험군의 월경불편감은 $51.95( \pm 37.98)$ 감소하였고, 대조군의 월경불편감은 $5.40( \pm 30.72)$ 증가하였으며 통계적으로도 유의하 였다 $(\mathrm{t}=5.25, \mathrm{p}=0.000)$. 그러므로 "쑥좌훈을 시행한 실험군의

Table 2. Homogeneity of the experimental and control group

$(\mathrm{N}=40)$

\begin{tabular}{lcccc}
\hline \multicolumn{1}{c}{ Variable } & Exp. group $(\mathrm{n}=20)$ & Cont. group $(\mathrm{n}=20)$ & \multirow{2}{*}{$\mathrm{t}$} & $\mathrm{p}$ \\
\cline { 2 - 3 } & $\mathrm{M} \pm \mathrm{SD}$ & $\mathrm{M} \pm \mathrm{SD}$ & 0.96 & .34 \\
MDQ score & $124.7 \pm 35.78$ & $114.85 \pm 28.49$ & & 0.16 \\
Dysmenorrhea intensity score & $8.08 \pm 1.42$ & $7.5 \pm 1.58$ & .69 & .09 \\
Prostaglandin F2a(ng/mL) & $1.26 \pm 0.26$ & $1.25 \pm 0.20$ & 0.09 \\
\hline
\end{tabular}

Table 3. Comparison of MDQ scores: Pre-post difference between experimental and control group

$(\mathrm{N}=40)$

\begin{tabular}{|c|c|c|c|c|}
\hline Variable & $\begin{array}{l}\text { Exp. } \operatorname{group}(n=20) \\
\text { Pre-Post }(M \pm S D)\end{array}$ & $\begin{array}{c}\text { Cont. group }(n=20) \\
\text { Pre-Post }(M \pm S D)\end{array}$ & $\mathrm{t}$ & $p$ \\
\hline Pain & $-9.70 \pm 7.50$ & $-1.15 \pm 6.16$ & 3.94 & .000 \\
\hline Muscle stiffness & $-1.25 \pm 1.45$ & $-0.45 \pm 1.67$ & 1.62 & .114 \\
\hline Headache & $-1.80 \pm 1.74$ & $-0.55 \pm 2.24$ & 1.98 & .056 \\
\hline Cramps & $-1.05 \pm 1.19$ & $0.35 \pm 1.23$ & 3.663 & .001 \\
\hline Backache & $-2.00 \pm 2.15$ & $0.40 \pm 2.39$ & 3.34 & .002 \\
\hline Fatigue & $-1.60 \pm 1.54$ & $-0.40 \pm 1.50$ & 2.50 & .017 \\
\hline General aches and pains & $-2.00 \pm 1.86$ & $-0.50 \pm 2.06$ & 2.00 & .053 \\
\hline Concentration & $-10.05 \pm 8.89$ & $2.45 \pm 9.43$ & 4.31 & .000 \\
\hline Insomnia & $-1.15 \pm 1.53$ & $-0.05 \pm 1.47$ & 2.32 & .026 \\
\hline Forgetfulness & $-1.00 \pm 1.21$ & $-0.30 \pm 1.89$ & 1.39 & .174 \\
\hline Confusion & $-1.30 \pm 1.34$ & $0.55 \pm 2.01$ & 3.42 & .002 \\
\hline Lowered judgment & $-1.40 \pm 1.19$ & $0.55 \pm 1.54$ & 4.49 & .000 \\
\hline Difficulty concentrating & $-1.55 \pm 1.54$ & $0.60 \pm 1.73$ & 4.16 & .000 \\
\hline Distractible & $-1.10 \pm 1.59$ & $0.05 \pm 1.39$ & 2.44 & .020 \\
\hline Accidents & $-0.75 \pm 1.25$ & $0.50 \pm 1.70$ & 2.65 & .012 \\
\hline Lowered motor coordination & $-1.80 \pm 1.88$ & $0.55 \pm 0.41$ & 4.02 & .000 \\
\hline Behavioral change & $-9.90 \pm 7.21$ & $-0.55 \pm 6.38$ & 4.86 & .000 \\
\hline Lowered school or work performance & $-1.85 \pm 2.06$ & $0.00 \pm 1.38$ & 3.34 & .002 \\
\hline Take naps: stay in bed & $-1.75 \pm 1.65$ & $0.15 \pm 0.39$ & 2.97 & .005 \\
\hline Stay at home & $-2.25 \pm 1.77$ & $-0.25 \pm 0.51$ & 3.88 & .000 \\
\hline Avoid social activities & $-2.25 \pm 1.68$ & $0.25 \pm 0.45$ & 4.41 & .000 \\
\hline Decreased efficiency & $-1.80 \pm 1.77$ & $0.25 \pm 0.52$ & 3.34 & .002 \\
\hline
\end{tabular}


Table 3. Comparison of $\mathrm{MDQ}$ scores: Pre-post difference between experimental and control group(continued) (N=40)

\begin{tabular}{|c|c|c|c|c|}
\hline Variable & $\begin{array}{l}\text { Exp. group }(n=20) \\
\text { Pre-Post }(M \pm S D)\end{array}$ & $\begin{array}{l}\text { Cont. group }(n=20) \\
\text { Pre-Post }(M \pm S D)\end{array}$ & $\mathrm{t}$ & $p$ \\
\hline Autonomic reactions & $-4.60 \pm 4.04$ & $0.80 \pm 5.06$ & 3.73 & .001 \\
\hline Dizziniss, faintness & $-1.90 \pm 1.86$ & $0.10 \pm 0.43$ & 3.35 & .002 \\
\hline Cold sweats & $-1.35 \pm 1.79$ & $0.05 \pm 0.48$ & 2.25 & .031 \\
\hline Nausea, vomiting & $-0.45 \pm 1.15$ & $0.65 \pm 0.31$ & 2.73 & .009 \\
\hline Hot flashes & $-0.90 \pm 0.97$ & $-0.00 \pm 0.32$ & 2.35 & .024 \\
\hline Water retention & $-3.60 \pm 4.19$ & $0.85 \pm 5.23$ & 2.97 & .005 \\
\hline Skin disorders & $-1.10 \pm 1.37$ & $0.25 \pm 0.32$ & 3.03 & .004 \\
\hline Painful breasts & $-1.15 \pm 1.63$ & $-0.15 \pm 0.53$ & 1.55 & .131 \\
\hline Swelling & $-0.90 \pm 1.29$ & $0.40 \pm 0.36$ & 2.82 & .008 \\
\hline Weight gain & $-0.45 \pm 1.28$ & $0.35 \pm 0.42$ & -0.47 & .639 \\
\hline Negitive affect & $-14.10 \pm 9.99$ & $1.90 \pm 8.48$ & 5.46 & .000 \\
\hline Crying & $-1.65 \pm 1.53$ & $0.30 \pm 0.37$ & 3.87 & .000 \\
\hline Loneliness & $-1.85 \pm 1.63$ & $-0.10 \pm 0.42$ & 3.16 & .003 \\
\hline Anxiety & $-1.30 \pm 1.30$ & $0.30 \pm 0.44$ & 3.02 & .004 \\
\hline Restlessness & $-1.60 \pm 1.79$ & $0.80 \pm 0.42$ & 4.14 & .000 \\
\hline Irritability & $-2.25 \pm 1.52$ & $-0.00 \pm 0.34$ & 4.68 & .000 \\
\hline Mood swings & $-1.85 \pm 2.18$ & $-0.05 \pm 0.32$ & 3.08 & .004 \\
\hline Depression & $-1.70 \pm 1.78$ & $0.05 \pm 0.43$ & 3.00 & .005 \\
\hline Tension & $-1.90 \pm 1.74$ & $0.60 \pm 0.37$ & 4.68 & .000 \\
\hline Total & $-51.95 \pm 37.98$ & $5.40 \pm 30.72$ & 5.25 & .000 \\
\hline
\end{tabular}

월경불편감은 시행하지 않은 대조군보다 낮을 것이다”라는 제 1 가설은 지지되었다.

\section{2) 쑥좌훈이 월경통 강도에 미치는 효과}

쑥좌훈 처치전후 실험군과 대조군간 월경통 변화 차이를 비교한 결과 실험군은 $5.28( \pm 2.84)$ 감소하였고, 대조군은 통증 이 0.18( \pm 1.38$)$ 증가하였으며 통계적으로도 유의하였다 $(\mathrm{t}=7.71$, $\mathrm{p}=0.000$ ). 그러므로 “쑥좌훈을 시행한 실험군의 월경통 강도 는 대조군보다 낮을 것이다"라는 제 2가설은 지지되었다.

3) 쑥좌훈이 prostaglandin F2 $\alpha$ 에 미치는 효과

처치전후 실험군과 대조군간 prostaglandin F $2 \alpha$ 농도 변화 차 이를 t-test를 통해 비교해 본 결과, 실험군은 $0.44( \pm 0.35) \mathrm{ng} / \mathrm{ml}$
감소하였고, 대조군은 $0.02( \pm 0.27) \mathrm{ng} / \mathrm{ml}$ 증가하였으며, 통계적 으로도 유의하게 나타났다 $(\mathrm{t}=4.56, \mathrm{p}=0.000)$. 그러므로 "쑥좌훈 을 시행한 실험군의 prostaglandin F2 $\alpha$ 는 대조군보다 낮을 것 이다"라는 제 3 가설은 지지되었다.

\section{논 의}

월경불편감 측정도구(MDQ)는 점수별로 79 미만을 경증, 80-119를 중등도증, 120 이상은 중증으로 분류되며(Lee, 2007), 본 연구에서는 쑥좌훈 처치 전 실험군의 월경불편감은 124.70 ( \pm 35.78$)$ 으로 중증에 속하였지만, 쑥좌훈 처치 후 72.75 $( \pm 31.94)$ 로 경증으로 변화된 것을 볼 수 있다. 또한 6 개 범주 의 35 문항 모든 증상에서 월경불편감이 감소되는 효과를 보

Table 4. Comparison of dysmenorrhea intensity scores: Pre-post differences between experimental and control group

\begin{tabular}{ccccc}
\hline \multirow{2}{*}{ Variable } & Exp. group $(\mathrm{n}=20)$ & Cont. group $(\mathrm{n}=20)$ & $\mathrm{t}$ & $\mathrm{p}$ \\
\cline { 2 - 4 } Dysmenorrhea & Pre-Post $(\mathrm{M} \pm$ SD) & Pre-Post(M \pm SD) & $0.18 \pm 1.38$ & 7.71 \\
\hline
\end{tabular}

Exp.=experimental; Con. $=$ control

Table 5. Comparison of prostaglandin F2 $\alpha$ levels: Pre-post differences between experimental and control group ( $\mathrm{N}=40$ )

\begin{tabular}{ccccc}
\hline \multirow{2}{*}{ Variable } & Exp. group $(\mathrm{n}=20)$ & Cont. group $(\mathrm{n}=20)$ & \multirow{2}{*}{$\mathrm{t}$} & \\
\cline { 2 - 3 } & Pre-Post $(\mathrm{M} \pm \mathrm{SD})$ & Pre-Post $(\mathrm{M} \pm \mathrm{SD})$ & 4.56 & .000 \\
\hline Prostaglandin F2a & $-0.44 \pm 0.35 \mathrm{ng} / \mathrm{ml}$ & $0.02 \pm 0.27$ & \\
\hline
\end{tabular}

Exp.=experimental; Cont. $=$ control 
였다. 이는 Dawood(1988)의 연구에서 $15-20 \%$ 의 중증 환자에 게 효과적이지 못했던 NSAIDs(약물복용) 보다 훨씬 효과적인 방법이며, Chan, Fuchs와 Powell(1983)가 NSAIDs를 적용한 결 과, 어지러움, 오심, 구토 등의 월경불편감에는 전혀 효과가 나타나지 않았던 것과 비교해 약물요법보다 쑥좌훈이 훨씬 더 효과적인 방법임이 확인되었다. 또한 쑥좌훈은 Shon(2005) 의 한방좌훈요법을 적용한 연구에서 월경불편감(0-110)이 처 치 전 54.96( \pm 14.18$)$ 에서 처치 후 48.92( \pm 13.04$)$ 로 $6.04( \pm 2.21)$ 감소된 것 보다 더 효과적이었고, $\operatorname{Bak}(2003)$ 의 아로마테라피 를 적용한 연구에서, 월경 1 일째 월경불편감 점수(35-210)는 처 치 전 $91.40( \pm 35.29)$ 에서 처치 후 $83.2( \pm 29.72)$ 로 $9.20( \pm 27.01)$ 감소된 결과보다도 효과적으로 나타났다. $\operatorname{Kim}(2004)$ 의 자가발 반사요법 연구에서, 처치 전 $120.91( \pm 27.06)$ 에서 처치 후 $86.38( \pm 23.98)$ 와도 차이가 있어 쑥좌훈이 월경불편감에 더 효 과적인 방법임이 확인되었다.

월경통은 월경통 정도에 따라 세 분류로 나뉜다. 4 미만을 경미한 통증, 4 이상 6 이하는 통증이 있어 약간 괴로우며 일상 생활의 반 정도를 수행 할 수 있는 중등도 통증이며, 7 이상은 통증이 심하고 일상생활을 조금 밖에 수행 할 수 없는 정도 의 통증으로 중증에 해당된다(Lee \& Kim, 2004). 본 연구에 서는 쑥좌훈 처치 전 $8.07( \pm 1.42)$ 이었던 중증의 월경통 강도 가, 쑥좌훈 후 경미한 통증인 $2.80( \pm 2.79)$ 으로 현저히 감소된 것을 볼 수 있는데, 이는 $\operatorname{Mun}(2004)$ 의 연구에서 1 일 3 회 60 환의 주자당귀환을 13 주간 경구 투여하여 7점이던 월경통 강 도가 4.88 로 감소된 것과 비교하여 쑥좌훈이 월경통 강도를 감소시키는데 더 효과적인 방법임이 확인되었다. 또한, Jun $(2003,2004)$ 의 연구에서 삼음교 지압 처치 전 $5.30( \pm 1.31)$, 처 치 후 2.73( \pm 1.53$)$ 으로 전후 $2.57( \pm-0.22)$ 의 감소보다 더 큰 수 치이며, Han 등(2001) 아로마테라피의 처치 전 7.40( \pm 1.27$)$, 처 치 후 4.26( \pm 2.36$)$ 보다 효과적이다. 또한 $\operatorname{Kim}(2004)$ 의 자가 발반사요법 후 4.04( \pm 1.91$)$, Lee(2005)의 자가 뜸요법 후 5.20 $( \pm 0.82)$ 보다 더 낮은 월경통 강도를 보이고 있어 쑥좌훈이 효과적인 방법임이 입증되었다.

본 연구에서는 처치 전 prostaglandin F2 $\alpha$ 농도가 $1.26( \pm 0.26)$ $\mathrm{ng} / \mathrm{ml}$ 에서 처치 후 $0.83( \pm 0.42) \mathrm{ng} / \mathrm{ml}$ 로 $0.44( \pm 0.35)$ 의 감소를 보여주고 있는데 이러한 연구결과는 소변 내 prostaglandin F2a 를 측정한 연구가 아직 보고 되지 않고 있어 다른 연구와 비 교하기는 어렵다. 그러나 비 약물요법을 적용한 $\operatorname{Bak}(2003)$ 의 아로마테라피 중재에서 혈장 prostaglandin $\mathrm{F} 2 \alpha$ 의 처치전후 비 교는 없었지만, 대조군과 비교하여 낮게 측정되었다고 보고하 였고, 이외 NSAIDs를 복용한 많은 연구들(Rosenwaks et al., 1981; Chan, Fuchs, \& Powell, 1983; Dawood, 1988)에서 혈장 및 월경혈 내 prostaglandin $\mathrm{F} 2 \alpha$ 가 감소되는 효과가 있었다.

추가분석으로 본 연구에서 월경불편감 및 월경통 정도와
소변 내 prostaglandin $\mathrm{F} 2 \alpha$ 와의 관계를 분석해 본 결과, 월경 불편감정도와 prostaglandin $\mathrm{F} 2 \alpha$ 농도( $\mathrm{r}=0.308, \mathrm{p}=0.005)$, 월경 통 강도와 prostaglandin $\mathrm{F} 2 \alpha$ 농도 $(\mathrm{r}=0.48, \mathrm{p}=0.000)$ 모두 정적 상관관계를 보였다.

\section{연구의 제한점}

- 본 연구설계시 일주기 처치의 지속효과를 검증할 목적으로 2-3개월까지 검증하려 하였으나 연구 참여자의 다양하고 복 합적인 외생변수 개입으로 인하여 할 수 없었음으로 지속 효과를 설명할 수 없음이 본 연구의 제한점이다.

- 본 연구에서의 처치인 쑥좌훈 요법이 쑥의 물질과 가열된 물질이란 점에서 열의 효과와 쑥 고유성분의 효과를 분리 할 수 는 없다.

\section{결론 및 제언}

\section{1. 결론}

쑥좌훈을 시행한 실험군의 월경불편감, 월경통 강도, 그리 고 prostaglandin F2a 농도는 대조군과 비교하여 유의하게 낮 게 나타났다. 따라서 이상의 결과를 볼 때, 쑥좌훈이 월경통 을 호소하는 여성들에게 있어 매우 효과적인 간호중재 방법 임이 확인되었고, 임상에 적용하여 활용할 가치가 있다고 사 료되어 본 연구는 매우 큰 의의가 있다고 본다.

\section{2. 제언}

본 연구의 결과를 토대로 쑥좌훈에 대한 추후 연구의 방향 과 간호실무 적용에 있어 다음과 같이 제언한다.

• 쑥좌훈 처치 후 지속효과 측정을 위한 장기적 설계연구를 제언한다.

• 쑥좌훈 처치 기간을 다양하게 설계하여 최적의 처치를 제시 하는 연구를 제언한다.

- 연구 결과를 일반화하기 위해 좀 더 많은 대상자를 확보하 여 효과를 검증할 수 있는 반복연구를 제언한다.

\section{References}

Bak, H. (2003). Effects of aromatherapy on perimenstrual syndrome and its relation to the prostaglandins. Unpublished doctoral dissertation. Yonsei University, Seoul.

Campbell, M. A., \& McGrath, P. J. (1997). Use of medication by adolescents for the management of menstrual discomfort. Arch Pediatr Adolesc Med, 151(9), 905-913. 
Chan, W. Y., Dawood M. Y., \& Fuchs, F. (1979). Relief of dysmenorrhea with the prostaglandin synthetase inhibitor ibuprofen: Effects on prostaglandin levels in menstrual fluid. American Journal of Obstetrics and Gynecology, 13, 102-108.

Chan, W. Y., Fuchs, F., \& Powell, A. M. (1983). Effects of naproxen sodium on menstrual prostaglandins and primary dysmenorrhea. Obstetetric Gynecol, 61(3), 285-291.

Chantay Banikarim, M. D., Mariam, R., Chacko, M. D., \& Kelder, S. H. (2000). Prevalence and Impact of Dysmenorrhea on Hispanic Female Adolescents. $A R C H$ PEDIATRA ADOLESC MED, 154, 1226-1229.

Choi, C. (1999). Reading Again Hwang-Je-Nae-Kyung 1,2, Seoul; Kukhakjaryowon.

Clayton, A. H. (2008). Symptoms related to the menstrual cycle: diagnosis, prevalence, and treatment. $J$ Psychiatr Pract, 14(1), 13-21.

Coco, M. D. (1999). Primary dysmenorrhea. American Family Physician, 60(2), 489-496.

Dawood, M. Y. (1988). Nonsteroidal anti-inflammatory drugs and changing attitudes toward dysmenorrhea. American Journal of Medicine, 20; 84(5A): 23-9.

Facchinetti, F., Fioroni, L., Sances, G., Romano, G., Nappi, G., \& Genazzani, A. R. (1989). Naproxen sodium in the treatment of premenstrual symptoms. A placebo-controlled study. Gynecol Obstet Invest, 28(4), 205-208.

Hanson, F. W., Izu, A., \& Henzl, M. R. (1978). Naproxen sodium in dysmenorrhea. Its influence in allowing continuation of work/school activities. Obstet Gynecol, 52(5), 583-587.

Han, S., Ro, Y., \& Hur, M. (2001). Effects of aromatherapy on menstrual cramps and dysmenorrhea in college student woman: A blind randomized clinical trial. Journal of Korean academy of Adult Nursing, 13(3), 420-430.

Hayes, K. W. (1993). Heat and cold in the management of rheumatoid arthritis. Arthritis Care Res, 6(3), 156-166.

Hu, J. (1997). The Dictionary of Dong-Eui-Bo-Gam. Seoul; Hanguksajunyungusa

$\mathrm{Hu}$, J. (Writer). The Research Center of DongEui (Translator) (2002). DongEuiBogam NaKyung, Humanist.

Jang, S., \& Jun, E. (2003). Effects of SP-6 acupressure on dysmenorrhea, cortisol, epinephrine and norepinephrine in the College Students. Journal of Nursing Academy Society, 33(7), 1038-1046.

Ji, J. (2004). (Through The Association of Doctor) Medical Dictionary. Seoul; Academia.

Jun, E. (2004). Effects of SP-6 Acupressure on dysmenorrhea, skin temperature. Journal of Nursing Academy Society, 34(7), 1343-1350.

Keele, K. D. (1948). The Pain Chart. Lancet, 2, 6-8.

Kim, M. (2004). The effect on self-foot reflexology on the relief of premenstrual syndrome and dysmenorrhea in high school girls. Dept. of Nursing Graduate School, Dong Eui University, Pusan.

Kim, J, Jo, Y., \& Hwang, S. (2005). The effect of Abdomen kyongrak massage on Menstrual cramps and dysmenorrhea in fulltime employed women. Journal of Nursing Academy Society, 35(7), 1325-1332.

Kim, J. (1995). Comprehensive understanding of perimenstrual discomfort; A triangulation of methods and perspectives. Unpublished master's thesis. Seoul University, Seoul.

Kim, T. (2005). Pathogenesis and management guideline of dysmenorrhea.. Korean Journal of Obstetrics and Gynecology, 48(7), 1613-1620.

Korean Association of Obstetricans and Gynecologist (1991). Gynecology and Obstetrics. Seoul; Calvin Serjuk.

Lee, S. (2007). The research on the characteristics of MMPI profile and Sasang constitutional on Dysmenorrhea Patients. Unpublished master's thesis. Won Kwang University, Iri.

Lee, I., \& Kim, G. (2004). A study on Instrumental Development of Menstrual Pain. The Journal of Oriental Obstetrics and Gynecololgy, 17(1), 138-159.

Mino, J. Moscatelli, V., Hnatyszyn, O., Gorzalczany, S., Acevedo, C., \& Ferraro, G. (2004). Antinociceptive and antiinflammatory activities of Artemisia copa extracts. Pharmacol Res, 50(1), 59-63.

Moos, R. H. (1968). The development of a menstrual distress questionnaire. Psychosomatic Medicine, 30(6), 853-867.

Mun, D. (2004). Clinical study on the Efficacy Jujadangguihwan for Dysmenorrhea whit Cold hypersensitivity. Unpublished master's thesis. Dong Eui University, Pusan.

Park, J. C., Yu, Y. B., Lee, J. H., \& Kim, N. J. (1994). Studies on the chemical components and biological activities of edible plants in Korea(VI). Anti-inflammatory and analgesic effects of Cedrela Sinensis, Oenanthe javanica and Artemisia var. orientals princeps. Journal of Korean Society Food Nutrient, 23(1), 116-119.

Peana, A. T., D'Aquila, P. S., Loredana Chessa, M., Moretti, M. D. L., Serra, G., \& Pippia, P. (2003). (-)-Linalool produces antinociception in two experimental models of pain. European Journal of Pharmacology, 460, 37-41.

Peana, A. P., Marzocco, S., Popolo, A., \& Pinto, A.(2006). (-)-Linalool inhibits in vitro NO formation: Probable involvement in the antinoceptive activity of this monoterpene compound. Life Sciences, 78, 719-723.

Pickles, V. R., Hall, W. J., Best, F. A., \& Smith, G. N. (1965). Prostaglandins in endometrium and menstrual fluid from normal and dysmenorrhoeic subjects. $J$ Obstet Gynaecol Br Commonw, 72, 185-192.

Professor, University of Oriental Medicine (2000). Bonchohak. Yungrimsa.

Rice, K. C., \& Wilson, R. S. (1976). (-)-3-Isothujone, a small nonnitrogenous molecule with antinociceptive activity in mice. J Med Chem 19, 1054-1057.

Rosenwaks, Z., Jones, G. S., Henzl, M. R., Dubin, N. H., Ghodgaonkar, R. B., \& Hoffman, S. (1981). Naproxen sodium, aspirin, and placebo in primary dysmenorrhea. Reduction of pain and blood levels of prostaglandin F2 $\alpha$ metabolite. Am J Obstet Gynecol, 140(5), 592-598.

Santos, F. A., \& Rao, V. S. (2000). Antiinflammatory and 
antinociceptive effects of 1, 8-cineol a terpenoid oxide present in many plant essential oils. Phytother Res, 14(4), 240-244.

Shon, I. (2005). The effect of the herb fumigation therapy on the relief of premenstrual syndrome and dysmenorrhea. Unpublished master's thesis. Pusan Catholic University, Pusan.

The Korean Society of pathologists (2003). Pathology. Seoul; Komunsa.
Warner, T. D., Giuliano, F., Vojnovic, I., Bukasa, A., Mitchell, J. A., \& Vane, J. R. (1999). Nonsteroid drug selectivities for cyclo-oxygenase-1 rather than cyclo-oxygenase-2 are associated with human gastrointestinal toxicity: A full in vitro analysis. Proc Natl Acad Sci USA, 96, 7563-7568.

Won, H. Y. (2003). Anti-inflammatory effects of Artemisia Cappillaris. Unpublished master's thesis. Wonkwang University, Iksan. 